\title{
KARAKTERISTIK PEMIKIRAN \\ DAN CORAK GERAKAN DAKWAH PONDOK PESANTREN
}

\author{
Wawan Trans Pujianto \\ Institut Agama Islam Negeri (IAIN) Metro \\ email : wawantranspujianto@gmail.com
}

\begin{abstract}
ABSTRACK
Symptoms of the trend of pesantren today also appear in the urban environment, such as the phenomenon of some pesantren students or students, such as in Malang, Al-Hikam, UlilAbsor, Firdaus, Dar al-Hijrah, and others. This trend shows that, although the pesantren education system has some weaknesses, it is still considered the most effective place to introduce Islam. Based on the condition of pesantren in such a way, then the concept of pesantren become a reflection of society thinking in educating and doing social change to society. Through this study, it is expected to give positive contribution in the form of information about the development of pesantren and the characteristics of thought and style of dakwah movement of pesantren to be socialized tothe community, especially the suggestion and recommendation and to support the development of pesantren in Indonesia.
\end{abstract}

Keywords: Movement of Da'wah, Pesantren 


\section{A. PENDAHULUAN}

Pesantren adalah bentuk pendidikan Islam yang sudah melembaga secara permanen di pedesaan. Bahkan, Pesantren merupakan Lembaga Pendidikn Islam tertua yang telah berfungsi sebagai salah satu benteng pertahanan umat Islam dan pusat dakwah serta pusat pengembangan masyarakat muslim di indonesia.

Gejala tren pesantren dewasa ini juga muncul dilingkungan perkotaan, seperti fenomena kemunculan beberapa pesantren mahasiswa atau pelajar, seperti di malang misalnya Al-Hikam, Ulil Absor, Firdaus, Dar al-Hijrah, dan beberapa yang lain. Kecenderungan ini menunjukkan, bahwa meskipun sistem pendidikan pesantren memiliki beberapa kelemahan, namun ternyata masih dianggap sebagai tempat paling efektif untuk memperkenalkan Islam.

Dengan melihat terjadinya dinamisasi di dalam ligkup pesantren, maka hal ini tetunya akan sedikit banyak terjadi perubahan karakteristik pemikiran dan corak gerakan dakwah yang dilakukan.

\section{B. SEJARAH PERTUMBUHAN PESANTREN}

Istilah pondok pesantren adalah merupakan dua istilah yang mengandung satu arti. Orang Jawa menyebutnya "pondok" atau "pesantren". Sering pula menyebut sebagai pondok pesantren. Istilah pondok barangkali berasal dari pengertian asrama-asrama para santri yang disebut pondok atau tempat tinggal yang terbuat dari bambu atau barangkali berasal dari bahasa Arab "فندق" artinya asrama besar yang disediakan untuk persinggahan.

Secara etimologi pesantren berasal dari kata santri yang mendapat awala pe- dan akhiran -an sehingga menjadi pe-santria-an yang bermakna kata "shastri" yang artinya murid. Sebagaimana yang dikemukakan oleh C.C. Berg bahwa istilah pesantren berasal dari kata "shastri" yang dalam bahasa India berarti orang yang tahu buku-buku suci agama Hindu, atau seorang sarjana ahli kitab-kitab suci agama Hindu. Kata shastri berasal dari kata shastra yang berarti buku-buku suci, buku-buku suci agama atau buku-buku tentang ilmu pengetahuan. ${ }^{1}$

Dari pengertian tersebut berarti antara pondok dan pesantren jelas merupakan dua kata yang identik (memiliki kesamaan arti), yakni asrama tempat santri atau tempat murid atau santri mengaji.

Secara terminologi pengertian pondok pesantren dapat penulis kemukakan dari pendapat para ahli antara lain: M. Dawam Rahardjo memberikan pengertian pesantren sebagai sebuah lembaga pendidikan dan penyiaran agama Islam, itulah identitas pesantren pada awal

${ }^{1}$ Yasmadi, Modernisasi Pesantren,(Jakarta, 2002), hal. 62 
perkembangannya. Sekarang setelah terjadi banyak perubahan di masyarakat, sebagai akibat pengaruhnya, definisi di atas tidak lagi memadai, walaupun pada intinya nanti pesantren tetap berada pada fungsinya yang asli, yang selalu dipelihara di tengah-tengah perubahan yang deras. Bahkan karena menyadari arus perubahan yang kerap kali tidak terkendali itulah, pihak luar justru melihat keunikannya sebagai wilayah sosial yang mengandung kekuatan resistensi terhadap dampak modernisasi. $^{2}$

Sedangkan dalam tulisan Karel A. Steenbrink, model pendiskripsinya masih bermuara pada seputar hubungan pesantren dengan warisan Hindu-Budha, atau juga hubungan pesantren dengan tradisi kebangkitan Islam abad pertengahan di Timur-Tengah. ${ }^{3}$

Ada dua versi pendapat mengenai asal usul dan latar belakang berdirinya pesantren di indonesia.

Pertama : pendapat yang menyebutkan bahwa pesantren berakar pada tradisi islam sendiri, yaitu tradisi tarekat. Pesantren mempunyai kaitan yang erat dengan tempat pendidikan yang khas bagi kaum sufi. Pendapat ini berdasarkan fakta bahwa penyiaran Islam di Indonesia pada awalnya lebih banyak dikenal dalam bentuk kegiatan tarekat. hal ini ditandai oleh terbentuknya kelompok-kelompok organisasi tarekat yang melaksanakan amalan-amalan dzikir dan wirid tertentu. Pimpinan tarekat itu disebut dengan Kiyai, yang mewajibkan pengikut-pengikutnya untuk melaksanakan suluk selama empat puluh hari dalam satu tahun dengan cara tinggal bersama-sama anggota tarekat dalam sebuah masjid untuk melakukan ibadah-ibadah dibawah bimbingan kiyai. Untuk keperluan suluk ini, para kiyai menyediakan ruang-ruang khusus untuk penginapan dan tempat memasak yang terletak dikiri kanan masjid. Disamping mengajarkan amalan-amalan tarekat, para pengikutnya juga diajarkan kitab-kitab agama dalam berbagai cabang ilmu pengetahuan. Akativitas yang dilakukan oleh pengikut-pengikut tarekat ini kemudian dinamakan pengajian. Dalam perkembangan selanjutnya lembaga pengajian itu tumbuh dan berkembang menjadi lembaga pesantren.

Kedua : pesantren yang kita kenal sekarang ini pada mulanya merupakan pengambil alihan dari sistem pesantren yang diadakan oleh orang-orang hindu Nusantara. Hal ini bersadarkan fakta bahwa jauh sebelum datangnya islam ke Indonesia, lembaga pesantren sudah ada di Negeri ini. Pendirian pesantren pada saat itu dimaksudkan sebagai tempat meengajarkan ajaran-ajaran Hindu dan tempat membina kader-kader penyebar Hindu. Tradisi penghormatan murid terhadap guru yang pola hubungan antara keduanya tidak didasarkan kepada hal-hal yang sifatnya

2Zamakhsyari Dhofier, Tradisi Pesantren,LP3ES, Jakarta, cet. 2. 1994, hlm. 18

${ }^{3}$ Karel A. Steenbrink, Pesantren Madrasah Sekolah (Jakarta: 1989), hal. 23. 
materi juga bersumber dari tradisi hindu. Fakta lain yang menunjukkan bahwa pesantren bukan berakar dari tradisi Islam adalah tidak ditemukannya lembaga pesantren di negara-negara lainya, sementara lembaga yang serupa dengan pesantren banyak ditemukan di dalam masyarakat Hindu dan Budha, seperti di India, Myanmar dan thailand. ${ }^{4}$

\section{SISTEM NILAI DALAM PESANTREN}

Dalam pembahasan sistem yang dikembangkan oleh pesantren adalah sebuah pranata yang muncul dari agama dan tradisi Islam. Secara khusus Nurcholis Madjid menjelaskan, bahwa akar kultural dari sistem nilai yang dikembangkan oleh pesantren ialah ahlu'l-sunnah wa-'l-jama'ah. ${ }^{5}$ Dimana, jika dibahas lebih jauh akar-akar kultural ini akan membentuk beberapa segmentasi pemikiran pesantren yang mengarah pada watakwatak ideologis pemahamannya, yang paling nampak adalah konteks intelektualitasnya terbentuk melalui "ideologi" pemikiran, misalnya dalam figh lebih didominasi oleh ajaran-ajaran syafi'iyah, walaupun biasanya pesantren mengabsahkan madzhab arba', begitu juga dalam pemikiran tauhid pesantren terpengaruh oleh pemikiran Abu Hasan al-Ash'ary dan juga al-Ghazali. ${ }^{6}$ Dari hal yang demikian pula, pola rumusan kurikulum serta kitab-kitab yang dipakai menggunakan legalitas ahlu sunnah wal jama'ah tersebut (madzhab Sunni).

Secara lokalistik faham sentralisasi pesantren yang mengarah pada pembentukan pemikiran yang terideologisasi tersebut, mempengaruhi pula pola sentralisasi sistem yang berkembang dalam pesantren. Dalam dunia pesantren legalitas tertinggi adalah dimiliki oleh Kyai, dimana Kyai disamping sebagai pemimpin "formal" dalam pesantren, juga termasuk figur yang mengarahkan orientasi kultural dan tradisi keilmuan dari tiaptiap pesantren. Bahkan menurut Habib Chirzin, keunikan yang terjadi dalam pesantren demikian itu, menjadi bagian tradisi yang perlu dikembangkan, karena dari masing-masing memiliki efektifitas untuk melakukan mobilisasi kultural dan komponen-komponen pendidikannya. ${ }^{7}$

\section{TUJUAN PENDIDIKAN PESANTREN}

Perbedaan dengan lembaga pendidikan yang lain yang pada umumnya menyatakan tujuan pendidikan dengan jelas misalnya dirumuskan dalam anggaran dasar. Maka pesantren, terutama pesantren-pesantren lama pada umumnya tidak merumuskan secara eksplisit dasar dan tujuan

${ }^{4}$ Ensiklopedi Islam, (Jakarta : Ichtiar Baru, Cet.4, 1997). Hl. 100-101

${ }^{5}$ Nurcholis Madjid, Bilik-Bilik Pesantren, (Jakarta: 1997), 31

${ }^{6}$ Ibid., h.32

${ }^{7}$ M. Dawam Rahardjo, Editor Pergulatan Dunia Pesantren (Jakarta: 1985), hal. 78 
pendidikannya. Hal ini terbawa oleh sifat kesederhanaan pesantren yang sesuai dengan motivasi berdirinya, dimana kyainya mengajar dan santrinya belajar, atas dasar untuk ibadah dan tidak pernah di hubungkan dengan tujuan tertentu dalam lapangan penghidupan atau tingkat dan jabatan tertentu dalam hirarki sosial maupun ekonomi.

\section{E. TIPOLOGI PESANTREN : MACAM-MACAM JENIS PESANTREN}

Secara garis besar, lembaga pesantren dapat digolongkan menjadi dua kelompok besar yaitu:

Pesantren Salafi : yaitu pesantren yang tetap mempertahankan sistem (materi pengajaran) yang sumbernya kitab-kitab klasik Islam atau kitab dengan huruf Arab gundul (tanpa baris apapun). Sistem sorogan (individual) menjadi sendi utama yang diterapkan. Pengetahuan non agama tidak diajarkan.

Pesantren Khalafi : yaitu sistem pesantren yang menerapkan sistem madrasah yaitu pengajaran secara klasikal, dan memasukan pengetahuan umum dan bahasa non Arab dalam kurikulum. Dan pada akhir-akhir ini menambahnya berbagai ketermpilan. ${ }^{8}$

\section{F. CORAK PEMBAHARUAN PESANTREN}

Menghadapi perubahan zaman yang begitu cepat, dunia pesantren mengalami pergeseran kearah perkermbangan yang lebih positif, baik secara struktural maupun kultural, yang menyangkut pola kepemimpinan, pola hubungan pimpinan dan santri, pola komunikasi, cara pengambilan keputusasan dan sebagainya, yang lebih memperhatikan prinsip-prinsip manajemen ilmiah dengan landasan nilai-nilai Islam. Dinamika perkembangan pesantren semacam inilah yang menampilkan sosok pesantren yang dinamis, kreatif, produktif dan efektif serta inovatif dalam setiap langkah yang ditawarkan dan dikembangkannya. Sehingga pesantren merupakan lembaga yang adaptif dan antisipatif terhadap perubahan dan kemajuan zaman dan teknologi tanpa meninggalkan nilai-nilai relegius.

\section{G. KRAKTERISTIK PEMIKIRAN DAN CORAK GERAKAN DAKWAH PESANTREN}

\section{Pondok Pesantren : Karakteristik dan Fungsinya}

Keberadaan pondok pesantren dan masyarakat merupakan dua sisi tidak dapat di pisahkan,karena keduanya saling mempengaruhi. Sebagian besar pesantren berkembang dari adanya dukungan masyarakat, dan secara sederhana muncul atau berdirinya pesantren merupakan inisiatif masyarakat baik secara individu maupun kolektif. Begitu pula sebaliknya perubahan sosial dalam masyarakat merupakan dinamika kegiatan pondok pesantren dalam pendidikan dan kemasyarakatan.

${ }^{8}$ Op.Cit., h10-20

Karakteristik Pemikiran Dan Corak .....

Wawan Trans Pujianto 
Berdasarkan kondisi pesantren yang sedemikian rupa,maka konsep pesantren menjadi cerminan pemikiran masyarakat dalam mendidik dan melakukan perubahan sosial terhadap masyarakat. Dampak yang jelas adalah terjadi perubahan orientasi kegiatan pesantren sesuai dengan perkembangan masyarakat. Dengan demikian pondok pesantren berubah tampil sebagai lembaga pendidikan yang bergerak dibidang pendidikan dan sosial. Bahkan lebih jauh daripada itu pesantren menjadi konsep pendidikan sosial dalam masyarakat muslim baik di desa maupun dikota.

\section{Tipologi Pondok Pesantren}

Pondok pesantren sebagai lembaga pendidikan islam mengalami perkembangan bentuk sesuai dengan perkembangan zaman,terutama sekali adanya dampak kemajuan ilmu pengetahuan dan teknologi. Perubahan bentuk pesantren bukan berarti sebagai pondok pesantren yang telah hilang kekhasannya. Dalam hal ini pondok pesantren tetap merupakan lembaga pendidikan Islam yang tumbuh dan berkembang dari masyarakat untuk masyarakat. Secara faktual ada beberapa tipe pondok pesantren yang berkembang dalam masyarakat, yang meliputi:

\section{a. Pondok Pesantren Tradisional}

Pondok Pesantren ini masih tetap mempertahankan bentuk aslinya dengan semata-mata mengajarkan kitab yang ditulis oleh ulama abad ke-I dengan menggunakan bahasa Arab. Pola pengajarannya dengan menerapkan sistem "halaqah" yang dilaksanakan di masjid atau mushola. Hakekat dari sistem pengajaran halaqoh adalah penghafalan yang titik akhirnya dari segi metodologi cenderung kepada terciptanya santri yang menerima dan memiliki ilmu. Artinya itu tidak berkembang ke arah paripurnanya ilmu itu, melainkan hanya terbatas pada yang di berikan oleh kyainya. Kurikulumnya tergantung sepenuhnya kepada para kyai pengasuh pesantren. Santrinya ada yang menetap di dalam pondok (santri mukim), dan santri yang tidak menetap di dalam pondok.

\section{b. Pondok Pesantren Modern}

Pondok pesantren ini merupakan pengembangan tipe pesantren karena orientasi belajarnya cenderung mengadopsi seluruh sistem belajar secara klasikal dan meninggalkan sistem tradisional. Penerapan sistem belajar modern ini terutama pada penggunaan kelas-kelas belajar baik dalam bentuk madrasah maupun sekolah. Kurikulum yang dipakai adalah kurikulum sekolah atau madrasah yang berlaku secara nasional. Santrinya ada yang menetap ada yang tersebar di sekitar desa itu. Kedudukan para kyai sebagai koordinator pelaksana proses belajar mengajar dan sebagai pengajar langsung di kelas. Perbedaannya dengan sekolah dan madrasah terletak pada porsi pendidikan agama dan bahasa Arab lebih menonjol sebagai kurikulum lokal. 


\section{c. Pondok Pesantren Komprehensif}

Pondok Pesantren Ini disebut komprehensif karena merupakan sistem pendidikan dan pengajaran gabungan yang tradisional dan yang modern. Artinya di dalamnya diterapkan pendidikan dan pengajaran kitab salaf dengan metode sorogan, bandongan dan wetonan, namun secara reguler sistem persekolahan terus di kembangkan. Bahkan pendidikan ketrampilan pun diaplikasikan terus di kembangkan. Bahkan pendidikan ketrampilan pun diaplikasikan sehingga menjadikannya berbeda dari tipologi kesatu dan kedua. Kebagi jauh dari itu pendidikan masyarakat pun menjadi garapannya. Dalam arti yang berkiprah dalam pembangunan sosial kemasyarakatan.

Ketiga tipe pondok pesantren di atas memberikan gambaran bahwa pondok pesantren merupakan lembaga pendidikan sekolah. Luar sekolah dan masyarakat yang secara langsung dikelola oleh masyarakat dan bahkan merupakan milik masyarakat karena tumbuh dari dan oleh masyarakat. Lembaga pendidikan sekolah sesuai dengan pengertian sekolah pada umumnya. Sebagai lembaga pendidikan baik dalam bentuk ketrampilan tangan, bahasa maupun pendalaman pendidikan agama Islam yang dilaksanakan melihat kegiatan sorogan,wetonan dan bandongan bahkan kegiatan pengajian yang dilaksanakan oleh para kyai di dalam pondoknya. Sedangkan sebagai lembaga pendidikan masyarakat terlihat dari kegiatan kemasyarakatan yang dilakukan oleh pondok pesantren dalam mengikuti perkembangan masyarakat lingkungan.

Sikap pesantren yang demikian telah bergerak jauh melampaui lembaga pendidikan lainnya. Bahkan pesantren telah nyata melaksanakan cita-cita pendidikan nasional tentang pembangunan manusia seutuhnya dan masyarakat seluruhnya. Dapat juga di katakan pesantren sebagai lembaga pengembangan masyarakat muslim sebagaimana prediksi Sudjatmoko yang menganggap lembaga pendidikan agama sebagai suatu kekuatan yang mampu berfungsi penting dalam sosial yang akan datang.

\section{Gerakan Dakwah Pesantren}

Jargon yang ada di pesantren "al-muhafadhah ala al-qadim alshalih wa al-ahd bi jadid al-ashlah" (mempertahankan tradisi masa lalu yang baik dan mengambil tradisi atau budaya baru yang lebih baik) merupakan model pesantren dalam pengembangan pemikiran yang harmoni. Sikap berusaha menjaga harmonitas ini membuat pesantren begitu adaptif, bukan saja terhadap pandangan klasik, melainkan juga terhadap pandangan kontemporer.

Maka tidak salah, dalam hal dakwah, pesantren mampu menyapa kemajemukan dalam masyarakat untuk menyampaikan substansi ajaran-ajaran Islam, tanpa harus menyisihkan budaya lokal, 
selama tidak bertentangan dengan tauhid. Konstruksi paradigma wacana keilmuan yang adaptif itulah yang kiranya menjadi bekal pesantren dalam dakwah secara dinamis, yaitu lebih mengedepankan substansi daripada cara.

Dengan sikap seperti ini, pesantren mempunyai banyak keuntungan dari segi eksistensinya di tengah-tengah kultur masyarakat yang majemuk. Pesantren mudah diterima menjadi bagian dari mereka, sehingga seringkali dilibatkan dalam berbagai kegiatan sosialkemasyarakatan.

Pesantren merupakan kubu pertahanan mental masa-masa kolonial Belanda. Artinya, pesantren tidak hanya sebagai lembaga pertahanan fisik terhadap intimidasi dan senjata penjajah, namun pesantren juga menjadi kubu pertahanan yang bersifat mental ataupun moral. Pemikiran Snouck Hurgronje yang berupaya mengasimilasikan kebudayaan Indonesia dengan Belanda tidak mencapai keberhasilan karena sistem pertahanan masyarakat Indonesia saat itu dominan dipengaruhi pesantren. Tentu, ini dikarenakan tradisi dan corak santri yang tidak mudah berasimilasi dengan budaya Barat, dalam hal ini Belanda sebagai penjajah.

Pesantren juga sukses dalam memberantas buta huruf pada masyarakat akar rumput masa penjajahan dengan sistem mengenalkan bahasa Arab Melayu. Di lain hal, pesantren merupakan lembaga pendidikan yang berbasis masyarakat muslim Indonesia yang pertama membuka isolasi kultural dengan dunia luar. Hal ini adalah bentuk kemampuan pesantren dalam mengaktualkan bahasa Arab. Turunannya adalah membuka wacana bangsa hingga dapat berinteraksi dengan dunia dan keilmuan yang lebih luas.

Dengan demikian, sistem pendidikan pesantren berhasil melahirkan tokoh-tokoh ulama, zuama', bahkan politikus, bahkan sampai saat ini pun dapat dibuktikan. Banyak tokoh-tokoh nasional sekarang pernah mengeyam pendidikan pesantren secara baik. K.H. Hasan Basri, tokoh dan ulama nasional mengatakan beberapa titik keberhasilan pesantren, antara lain:

a. Berhasil menanamkan iman yang kokoh dalam jiwa para santri sehingga mereka memiliki daya dan semangat juang yang tinggi untuk Islam.

b. Bersikap tegas menentang kekafiran dan kebatilan secara konsekuen dan menyatukan diri dengan golongan pergerakan yang mempunyai pandangan yang sama.

c. Mampu membentuk kecerdasan (intelektualitas) dan kesholehan (moralitas) pada diri para santri, menguasai ilmu-ilmu yang diajarkan, dan membina diri untuk memiliki akhlak terpuji. 
d. Mampu membentuk masyarakat yang bermoral dan beradab berdasarkan ajaran Islam (masyarakat santri) sehingga menjadi kekuatan sosial dengan pengaruhnya yang besar dalam masyarakat bangsa Indonesia.

e. Menjadikan dirinya bagaikan benteng terakhir pertahanan terakhir ummat Islam dari serangan Kebudayaan Barat yang dilancarkan pemerintah kolonial Belanda. Dengan kata lain, pesantren berhasil menyelamatkan kebudayaan Islam di Indonesia.

f. Pesantren dan masyarakat santrinya adalah satu-satunya lembaga pendidikan di Indonesia yang tidak mengenal kompromi atau bekerja sama dengan pemerintah kolonial Belanda.

g. Dalam menghadapi arus perubahan sosial, politik, ekonomi, dan kebudayaan yang melanda bangsa Indonesia, ternyata masih tetap menunjukkan vitalitasnya untuk tetap berperan sebagai salah satu kekuatan sosial yang penting bagi peradaban Islam di Indonesia, baik masa kini maupun masa mendatang. Pesantren juga ternyata tidak tergilas oleh arus perkembangan lembaga-lembaga pendidikan modern yang berkiblat ke Barat.

Penjelasan-penjelasan di atas memperlihatkan bahwa pesantren, dulu ataupun sekarang, merupakan lembaga yang berhasil membentuk karakter-karakter pribadi muslim (santri) dan memiliki peranan besar dalam membina ummat dan bangsa hingga ke pelosok pedesaan.

\section{H. PERANAN PESANTREN}

Dalam perjalanan sejarah Indonesia pesantren telah memainkan peranan yang besar dalam usaha memperkuat iman, meningkatkan ketakwaan, membina akhlak mulian dan mengembangkan swadaya masyarakat Indonesia dan ikut mencerdaskan kehidupan bangsa melalui pendidikan informal, nonformal, dan pendidikan formal yang diselenggarakannya.

Secara informal lembaga pesantren di Indonesia telah berfungsi sebagai keluarga yang membentuk watak dan kepribadian santri. Pesantren ini juga telah melaksanakan pendidikan keterampilan melalui kursus-kursus untuk membekali dan membantu kemandirian para santri dalam kehidupan masa depannya sebagai muslim dan juga Da'i dan pembina masyarakat.

Secara keseluruhan pesantren selalu dijadikan contoh dan panutan dalam segala hal yang dilakukan atau dianjurkan untuk dilaksanakan oleh msyarakat, sehingga keberadaan pesantren di Indonesia itu telah berperan menjadi potensi yang sangat besar dalam pengembangan masyarakat, terutama masyarakat muslim lapisan menengah kebawah. ${ }^{9}$

${ }^{9}$ Ensiklopedi Islam, Loc.Cit., hl.105

Karakteristik Pemikiran Dan Corak ..... 


\section{PROSPEK PESANTREN DIMASA DEPAN : PELUANG DAN TANTANGAN}

Dalam Khozin jejak-Jejak Pendidikan Islam Di Indonesia lembaga pendidikan terutama yang berbasis diperdesaan telah mengalami sejarah yang panjang, sejak sekitar abad ke-18. Dengan berjalannya waktu, pesantren sedikit demi sedikit maju, tumbuh dan berkembang sejalan dengan proses dan dinamika masyarakatnya. Ini menunjukkanupayaupaya yang dilakukan pesantren untuk mendinamisir, sejalan dengan tuntutan dan perubahan masyarakat

Lembaga pendidikan Islam yang relatif tua di Indonesia tampak dalam beberapa hal. Pertama peningkatan secara kuantitas terhadap jumlah pesantren. Tercatat di Departemen Agama, bahwa pada tahun 1977 ada 4.19 pesantren dengan jumlah santri 677.384 orang. Jumlah tersebut menjadi 5661 pesantren dengan 938397 santri pada tahun 1981,10 kemudian meningkat lagi menjadi 15900 pesantren dengan jumlah santri 5,9 juta pada tahun 1985.11 Kedua, kemampuan pesantren untuk selalu hidup di tengah-tengah masyarakat yang sedang mengalami perubahan. Pesantren mampu memobilisasi sunber dana maupun tenaga, serta mampu berperan sebagai benteng terhadap berbagai budaya yang berdampak negatif. Kenyataan ini juga menunjukkan bahwa pesantren merupakan lembaga pendidikan yang mempunyai kekuatan untuk survive. Pesantren juga merupakan lembaga yang tepat dalam mendinamisir dirinnya di tengahtengah perubahan masyarakatnya. Secara sosiologis, ini menunjukkan bahwa pesantren masih memiliki fungsi nyata yang dibutuhkan masyarakat. ${ }^{12}$

Selain peluang di atas tersebut saat ini pesantren dihadapkan pada tantangan seperti kemampuan pesantren dalam memperebutkan peserta didik, seperti menurut Dhoifer, bahwa dominasi pesantren dalam dunia pendidikan mulai menurun secara drastis setelah tahun 1950-an salah satu faktornya adalah lapangan pekerjaan modern mulai terbuka yang mendapat latihan-latihan di sekolah umum. Hal ini mengakibatkan menurunnya minat kaum muda terhadap pendidikan pesantren dibanding dengan sekolah-sekolah umum, sementara perhatian pemerintahan sejak proklamasi terhadap sistem pendidikan nasional.

Namum, demikian, penulis berkesimpulan lembaga pendidikan pesantren prospeknya masih sangat menjanjikan, dan tetap akan berkembang sepanjang waktu dengan dinamika dan prosesnya yang berbeda.

${ }^{10}$ Aksyari Dhofier, Tradisi Pesantren, (Jakarta:, 1994), h.1

${ }^{11}$ Ibid., hal 102.

${ }^{12}$ Kertakusuma dalam khozin, jejak-jejak pendidikan Islam Di Indonesia (Malang ;2006) hal 107.

Karakteristik Pemikiran Dan Corak .....

Wawan Trans Pujianto 


\section{J. KESIMPULAN}

Keberadaan pesantren merupakan patner yang ideal bagi institusi pemerintah untuk bersama-sama meningkatkan mutu pendidikan yang ada di daerah sebagai basis bagi pelaksanaan Transformasi sosial melalui penyediaan sumber daya manusia yang qualified dan berakhlakul karimah. Terlebih lagi, proses transformasi sosial di era otonomi mensyaratkan daerah lebih peka menggali potensi lokal dan kebutuhan masyarakatnya sehingga kemampuan yang ada dalam masyarakat dapat dioptimalkan. Untuk dapat memainkan peran edukatifnya dalam penyediaan sumber daya manusia yang berkualitas mensyaratkan pesantren harus meningkatkan mutu sekaligus memperbaruhi model pendidikannya. Sebab, model pendidikan pesantren yang mendasarkan diri pada system konvensional atau klasik tidak akan banyak cukup membantu dalam penyediaan sumber daya manusia yang memiliki kompetensi integratif baik dalam penguasaan pengetahuan agama, pengetahuan umum dan kecakapan teknologis.

\section{DAFTAR PUSTAKA}

Aksyari Dhofier, Tradisi Pesantren, (Jakarta:, 1994),

Ensiklopedi Islam, (Jakart : Ichtiar Baru, Cet.4, 1997).

Karel A. Steenbrink, Pesantren Madrasah Sekolah (Jakarta: 1989).

Kertakusuma dalam khozin, jejak-jejak pendidikan Islam Di Indonesia (Malang :2006).

M. Dawam Rahardjo, Editor Pergulatan Dunia Pesantren (Jakarta: 1985).

Muhammad Ya'cub, Pondok Pesantren dan Pembangunan Desa, (Bandung: 1984).

Nurcholis Madjid, Bilik-Bilik Pesantren, (Jakarta: 1997).

Yasmadi, Modernisasi Pesantren, (Jakarta, 2002).

Zamakhsyari Dhofier, Tradisi Pesantren, LP3ES, Jakarta, cet. 2. 1994. 